\title{
Riparian classification to benchmark reclamation of the Athabasca oil sands
}

\author{
C.A. Daly Reclamation and Closure Planning, Suncor Energy Inc., Canada
}

H.B. Anderson Reclamation and Closure Planning, Suncor Energy Inc., Canada

A. Campbell Environmental Sustainability, Shell Canada Energy, Canada

F. Kuzmic Environment Department, Shell Canada Energy, Canada

\begin{abstract}
A Riparian Classification and Reclamation Guide ('Riparian Guide') was recently produced to direct the reestablishment of riparian ecosystems in areas disturbed by oil sands mining in Alberta, Canada. The Riparian Guide presents information on the identification, characterisation, and implementation of revegetation and monitoring protocols on reclaimed landscapes within the oil sands region. The purpose of the guide was to provide a classification system and tools associated with plant species and community interactions that can be used to effectively reclaim and revegetate disturbed riparian ecosystems. The Riparian Guide thus provides a framework for interpreting the environmental conditions of sites to be reclaimed, plant species requirements, landscape design and management objectives to facilitate reclamation activities and aid in the re-establishment of plant communities that were representative of riparian vegetation. An overview of the process that led to the development of the Riparian Guide is presented, including monitoring and riparian classification system that formed the foundation of the guide, a species selection tool, and a peer review. Finally, the riparian species selection tool is tested in a field program and the preliminary results of this test are reviewed.
\end{abstract}

\section{$1 \quad$ Introduction}

Until recently, revegetation of reclaimed lands in the Athabasca oil sands region in northeastern Alberta, Canada has predominantly focused on upland forests (CEMA, 2010; Renault et al., 1998). Lately, significant efforts have focused on revegetation of aquatic areas, mainly wetlands (Calvo-Polanco et al., 2012; Pouliot et al., 2012; Rezanezhad et al., 2012; Trites and Bayley, 2009) due to their significant presence in the natural landscape (Vitt et al., 1996) and now the riparian areas that surround them (GDC, 2009). Riparian areas are the pieces of land between a river, stream, lake or wetland and the drier upland where the soils are influenced by water (Harris, 2007) and support vegetation characteristic of high moisture conditions. They are an integral part of the natural environment since they provide a range of ecosystem services such as erosion control, water quality improvement, flood control and water storage and maintenance of biodiversity (AENV, 2007).

In the Athabasca oil sands region the landscape is disturbed by either in situ or open pit mining activities to recover bitumen from below the surface. Open pit mining removes entire landscapes, which as required by law, operators must reconstruct and revegetate to achieve equivalent capability. In contrast, when the bitumen is too deep for open pit mining in situ recovery methods are applied whereby wells are drilled into the ground and steam, air or solvents are injected to separate the oil from the sand. By law, mining disturbances must be reclaimed to a state of 'equivalent land capability' (OSWWG, 2000). Since wetlands, streams, and end pit lakes are integral components of oil sands mine closure, it is important that the riparian areas surrounding them are also reclaimed after disturbance in order to re-establish functional ecosystems and biodiversity. 
There are some challenges to revegetating oil sands after mining. First, elevated concentrations of sodium $(\mathrm{Na})$, sulfate $\left(\mathrm{SO}_{4}{ }^{2-}\right)$, calcium $(\mathrm{Ca})$, bicarbonate $\left(\mathrm{H}^{2} \mathrm{CO}_{3}{ }^{-}\right)$and chloride $(\mathrm{Cl})$ are present in some of the materials, such as tailings and overburden soils, used to construct reclaimed watersheds. Overburden is the layer of material (shale and mineral soils) between the organic surface soils and underlying bitumen ore. These salts are from the natural geological units of marine origin present in the region and the historical additions of gypsum $\left(\mathrm{CaSO}_{4} 2 \mathrm{H}_{2} \mathrm{O}\right)$ used to produce Consolidated Tailings (CT). Elevated salinity causes toxic accumulation of ions in plants which inhibits plant growth (Jacobs and Timmer, 2005; Timmer and Teng, 2004). Excess soluble salts in the root zone may also restrict plant roots from withdrawing water from the surrounding soil, effectively reducing available water to plant communities (Warrence et al., 2002). However, many native riparian and aquatic plants are capable of tolerating high salinity (Calvo-Polanco et al., 2012; Pouliot et al., 2012; Rezanezhad et al., 2012; Trites and Bayley, 2009) and are found in saline wetlands and lakes in the boreal forest of northern Alberta and Saskatchewan (Hammer, 1993; Trites and Bayley, 2009). Furthermore, saline-sodic soils are capped with a minimum of $1 \mathrm{~m}$ of low-sodicity materials, including a $50 \mathrm{~cm}$ organic cover soil cap, to reduce the potential for leaching of salts into the plant rooting zone. Second, oil sands reclamation had never focused on riparian areas before. Thus, there was little design and revegetation knowledge base to build upon.

This paper reviews the process which led to the development of the Riparian Guide for the oil sands mining industry. The Riparian Guide was developed in order to provide a classification system and associated information regarding autecology, synecology (the relationship between the environment and a particular species or community of species, respectively) and landscape reclamation for riparian ecosystems that could be used to design and revegetate areas disturbed by oil sands mining. More specifically, the guide was established to: (1) Identify, describe and characterise native riparian plant communities and plant species in relation to soil, site, landform, nutrient and hydrological conditions; and (2) Identify the abiotic characteristics that determine plant community establishment in riparian ecosystems.

A research program using information in the Riparian Guide is also reviewed. Plots of riparian revegetation were established around a reclaimed wetland in order to investigate whether planted riparian areas increased biotic diversity and abundance and reduced colonisation by weeds compared with the current standard for wetland and riparian reclamation - unassisted colonisation.

\section{$2 \quad$ Methodology}

The detailed methodology for this Riparian Guide development is available in GDC (2009). A brief synthesis is described in the following sections.

\subsection{Data collection, processing and analysis}

Vegetation, soil, site characteristics and other environmental variables were collected on natural and oil sands reclaimed sites near lake, wetland, river and streams between 2004 and 2006. In total, 62 transects were established on Shell Canada Energy (Shell), Suncor Energy Inc. (Suncor) and Syncrude Canada Ltd. (Syncrude) leased areas and data was collected from 292 plots. Although natural and reclaimed plots were distributed across a wide range of landscape and ecological conditions there still remained significant gaps in the data, particularly in natural saline and sodic landscapes. Therefore, data from an additional 197 plots were acquired from the literature (Purdy et al., 2005; Golder, 2005) to give a total of 489 plots.

A belt transect system approach was modified from Korol (1996) whereby a series of quadrats were strung together to evaluate environmental gradients. Transects were $20 \mathrm{~m}$ in width, perpendicular to the shoreline and extended from the terrestrial/aquatic interface $(0 \mathrm{~m})$ to the prominent upland plant community (20-90 m length in total, depending on the sample location) (Figure 1a). Plots were placed along transects at set intervals to describe plant communities within each dominant physiognomic growth form. Where trees and shrubs covered $<5 \%$ of the area, a $2.5 \mathrm{~m}$ interval was installed to describe dominant forb and graminoid physiognomic groups. A $5.0 \mathrm{~m}$ interval was applied to shrub and tree physiognomic 
plant communities for stands less than $25 \mathrm{~m}$ in length. A $10.0 \mathrm{~m}$ interval was applied to upland shrub and tree physiognomic plant communities that were greater than $25 \mathrm{~m}$ in length.

A nested design was used for vegetation sampling (Figure $1 \mathrm{~b}$ ). Base plots were $5 \times 20 \mathrm{~m}$, within which a series of randomly assigned, nested quadrats were used to sample different vegetation strata. Base plots were used to inspect canopy and understory species and mensuration data. The shrub stratum was sampled within a nested $5 \times 10 \mathrm{~m}$ quadrat, randomly assigned to the left side or right side of the $5 \times 20 \mathrm{~m}$ plot. Forb, graminoid, moss and lichen strata were further sampled within a $2.5 \times 10 \mathrm{~m}$ quadrat nested within a $5 \times 10 \mathrm{~m}$ quadrat and randomly assigned to either upper side or lower side of the $5 \times 10 \mathrm{~m}$ quadrat.

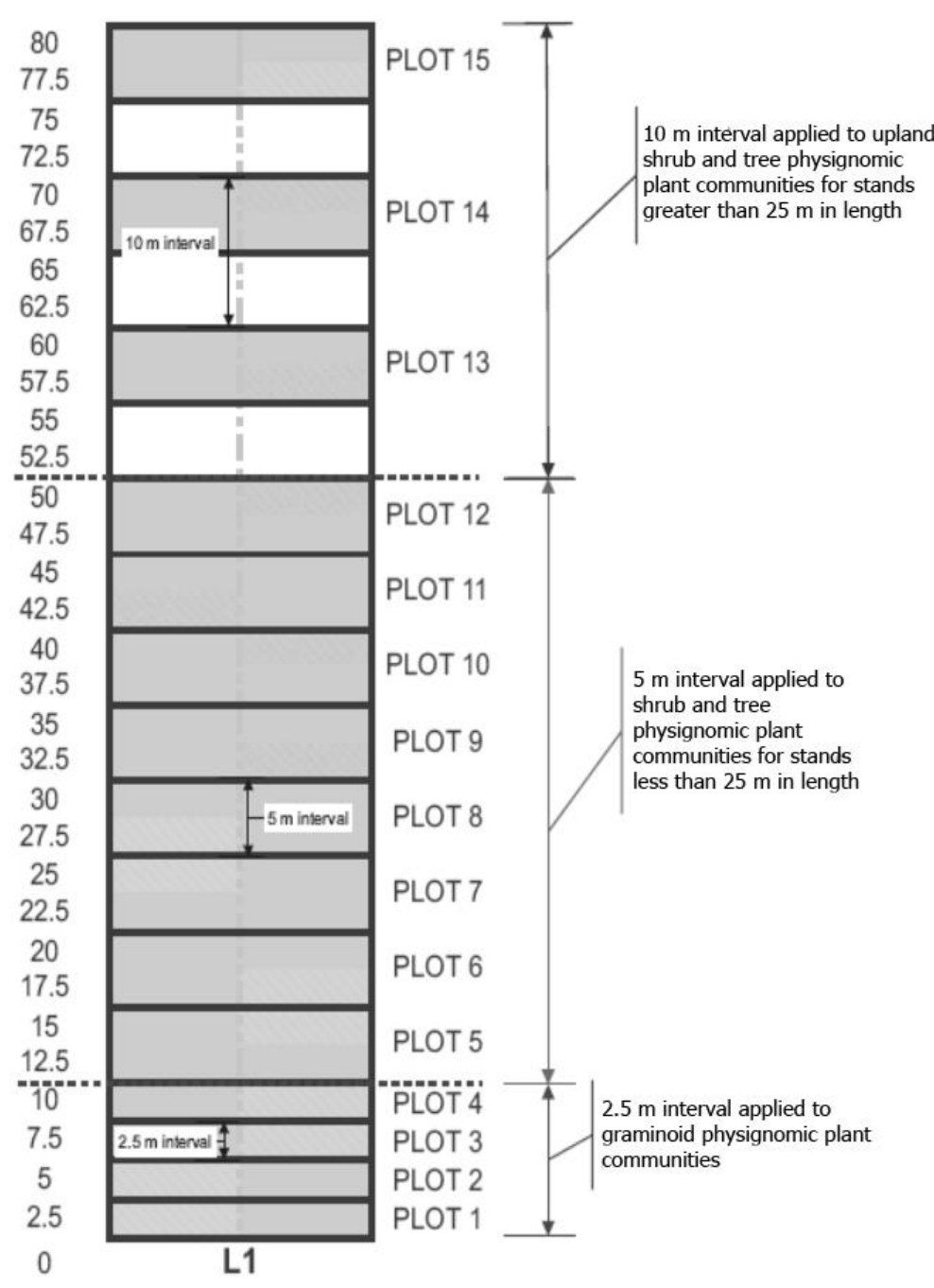

(a)

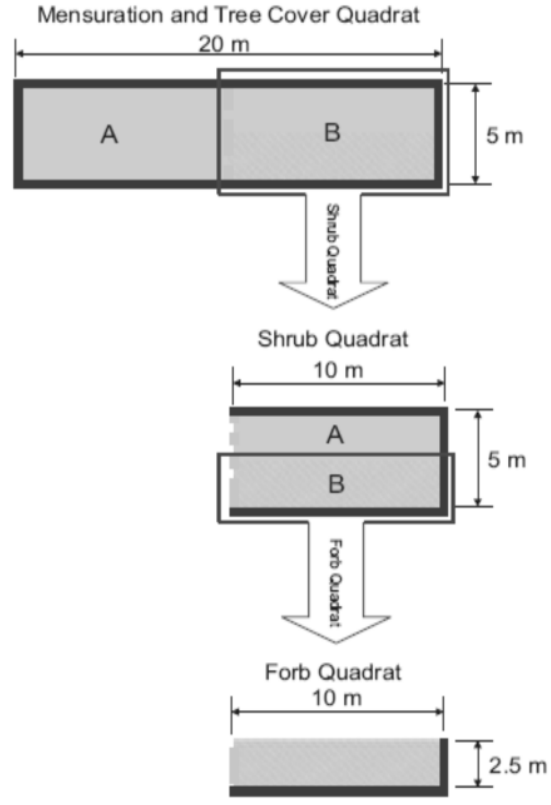

(b)

Figures 1 (a) Illustration of a riparian transect sample design with corresponding plot, distance and interval information. Shaded areas indicate quadrats where plots were established, while clear areas have no plots. (b) Illustration of a nested quadrat design used to record vegetation data within different strata (modified from GDC, 2009)

GPS points were collected at the beginning and end points of each transect. Elevation was measured at each distance interval. The following data was collected for each plot along each transect: vegetation information (plant species, percent cover, strata, diameter at breast height, height, crown class and site index trees), coarse woody debris (species, diameter class and decay class); soil information (humus form, parent material, surface expression, depth to effective rooting/water table/bedrock/frozen layer/root restriction/carbonates/salinity, horizon designations/depths/thickness/texture/coarse fragment contact, 
primary and secondary structure, consistency, $\mathrm{pH}$, effervescence (it is the escape of gas or fizzing produced by the application of acid to soils containing carbonate), primary and secondary colour, mottles, and primary and secondary roots) and site data (natural subregion according to Beckingham and Archibald (1996), site exposure, flood hazard, soil drainage, soil perviousness (the degree to which water can move through soil), site position, microtopography, site shape, moisture regime, nutrient regime, \% cover of surface substrates (decaying wood/bedrock/cobbles/stones/mineral soil/organic matter/water), elevation, aspect, and slope).

\subsection{Development of the riparian classification system}

A classification system was developed through data analysis, expert opinion and literature review that best captures the range of sites and plant communities that were expected on both reclaimed and natural sites. Multivariate data analyses (i.e. Twinspan, Canonical Correspondence Analysis (CCA) and Non-metric Multidimensional Scaling) were applied to investigate plant community relationships alone and in conjunction with environmental and soil-property data using PC-ORD software (McCune and Mefford, 1999). However, the data from the literature did not have the full suite of environmental variables that were collected in the field program, so zones were assigned intuitively based on site locations, data evaluation, and expert knowledge of plant species indicators of soil moisture and drainage conditions.

\subsection{Riparian revegetation tool}

A 'riparian species selection tool' was produced to guide the selection of riparian plants best suited for establishment in reclaimed riparian areas. It was developed based on the observed distribution of 70 riparian species monitored in reclaimed and natural area on a moisture and salinity grid or hygrosalinatope, since soil moisture and salinity were identified as the main factors controlling riparian plant community establishment (Section 3.1). The hygrosalinatope was composed of 25 positions with each species scored from 0 to 20, with 20 representing the position(s) of highest occurrence frequency and cover. Possible scores were $0,1.75,2.5,5,10,15$, and 20. A matrix of all the species scores served as the basis for the tool.

\subsection{Peer review}

A peer review was conducted on the Riparian Guide to evaluate its accuracy, rigor of methods, and the justifiability of the guide's conclusions based on the current state of knowledge in this field. It was facilitated by the Cumulative Environmental Management Association's (CEMA) Aquatic Subgroup who commissioned the Forestry Corporation (TFC) to complete an independent review based on how well the draft guide met its stated goals. Peer review was carried out using a quantitative approach whereby objectives and assessment criteria were assigned to the goals identified in the Riparian Guide and defined. The assessment criteria were weighted (to indicate importance) and scored (to assess relevance, accuracy and completeness). Weighted scores for assessment criteria were summed to provide an overall score for the Riparian Guide. A peer review report was produced that summarised these findings and this report was peer reviewed by three subject matter experts as part of a second level of review.

\subsection{Field trials}

The riparian species selection tool was used to guide revegetation of the wetland on Suncor's Wapisiw Lookout (previously known as Pond 1). Pond 1 was designed to hold tailings and constructed at Suncor in 1966; it was used to store tailings until 1997. In 1999, reclamation activities commenced on the pond whereby ponded water and some soft tailings (an aqueous suspension of silt, sand, clay and residual bitumen) were pumped to other tailings ponds on Suncor's site. Simultaneously, coarse sandy tailings were placed in the pond. Once the pond was filled and a solid surface was achieved, the area was contoured to establish a landscape with rolling hills ('hummocks') and streams ('swales') that direct precipitation falling within the 220 ha watershed down to a small wetland (Wapisiw Wetland). A geosythetic liner was placed under the swales and wetland and capped with $30 \mathrm{~cm}$ of coarse sandy tailings. Low sodic subsoil $(30 \mathrm{~cm})$ 
capped with forest floor soil or 'LFH' $(20 \mathrm{~cm})$ was placed over the sand in three large polygons (approximately 100-200 m wide by $50 \mathrm{~m}$ long) around the wetland shorelines. The subsoil was stockpiled for approximately four months prior to placement and the LFH was directly placed from a recently disturbed forest. Peat-mineral soil was placed over the remainder and majority of the wetland edges and throughout the adjoining area. Peat-mineral soil was placed at the wetland base or under the surface of the water. Water was pumped from a reference lake (electrical conductivity $780 \mathrm{uS} / \mathrm{cm}, \mathrm{pH} 8.7$ ) for a few days starting on July 4, 2010 to fill the wetland up to $70 \%$ of the maximum water level (1.5 m deep). The wetland reached its maximum water depth in August 2010 after a series of rain events. An overflow pipe connected to an overflow weir and sump adjacent to the wetland collected excess water during major rain or snowmelt events and directed it downstream to an adjacent pond.

Twelve research plots $(9 \mathrm{~m}$ (water's edge) $\times 30 \mathrm{~m} \times 12 \mathrm{~m}$ (highest elevation)), the riparian revegetation plots, were established around the edges of the wetland using planting prescriptions recommended by the 'riparian species selection tool' in the Riparian Guide (GDC, 2009) (Figure 2). Plots were staked within either regions of peat-mineral soil $(n=6)$ or LFH cover soil $(n=6)$ on the west side of the wetland on July 21, 2010. Half of the plots were randomly selected to be planted and the other half not.

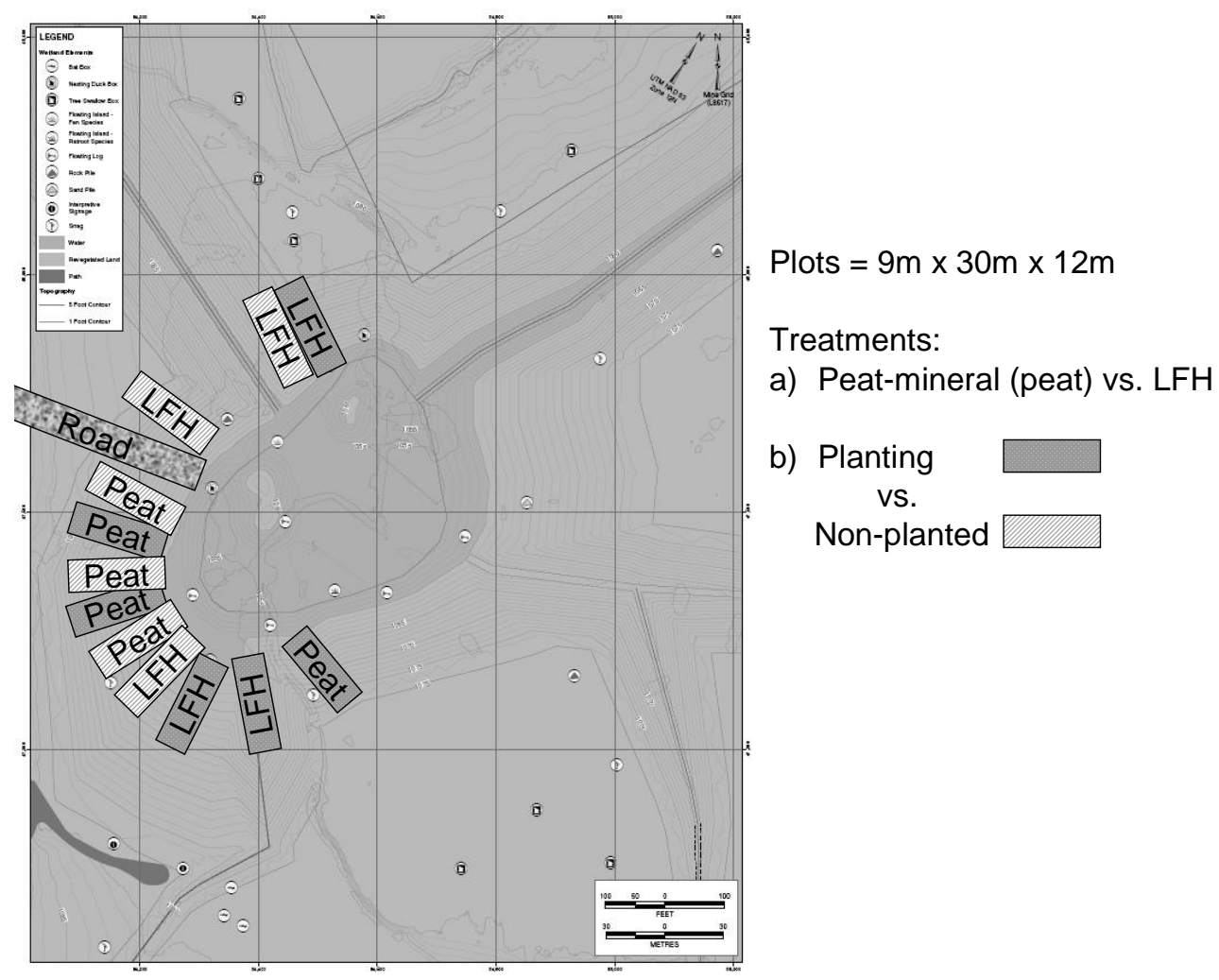

Figure 2 Experimental riparian revegetation plots on Wapisiw lookout

Salinity in the wetland was expected to remain low or non-saline over the long term $(S A R<12$ and $E C<2.0)$ (group 1) since the main water source into the wetland watershed is precipitation and runoff. Soil moisture regime (SMR) around the shoreline or flooded lowland $(2 \mathrm{~m}$ into the water from the shoreline and $3 \mathrm{~m}$ uphill from the water line) was designated hydric (zone 5; SMR = 8 to 9; Section 3.1) (Figure 3). The remaining area ( $25 \mathrm{~m}$ long) within the plots uphill from the lower hydric zone was designated transitional upland (zone 3; SMR = 6-7; Section 3.1). Consequently, a SMR of 8 and salinity 1 (non-saline) and SMR of 6 and 1 were used to inform selection of riparian-plant species for the flooded lowland and transitional upland, respectively. 


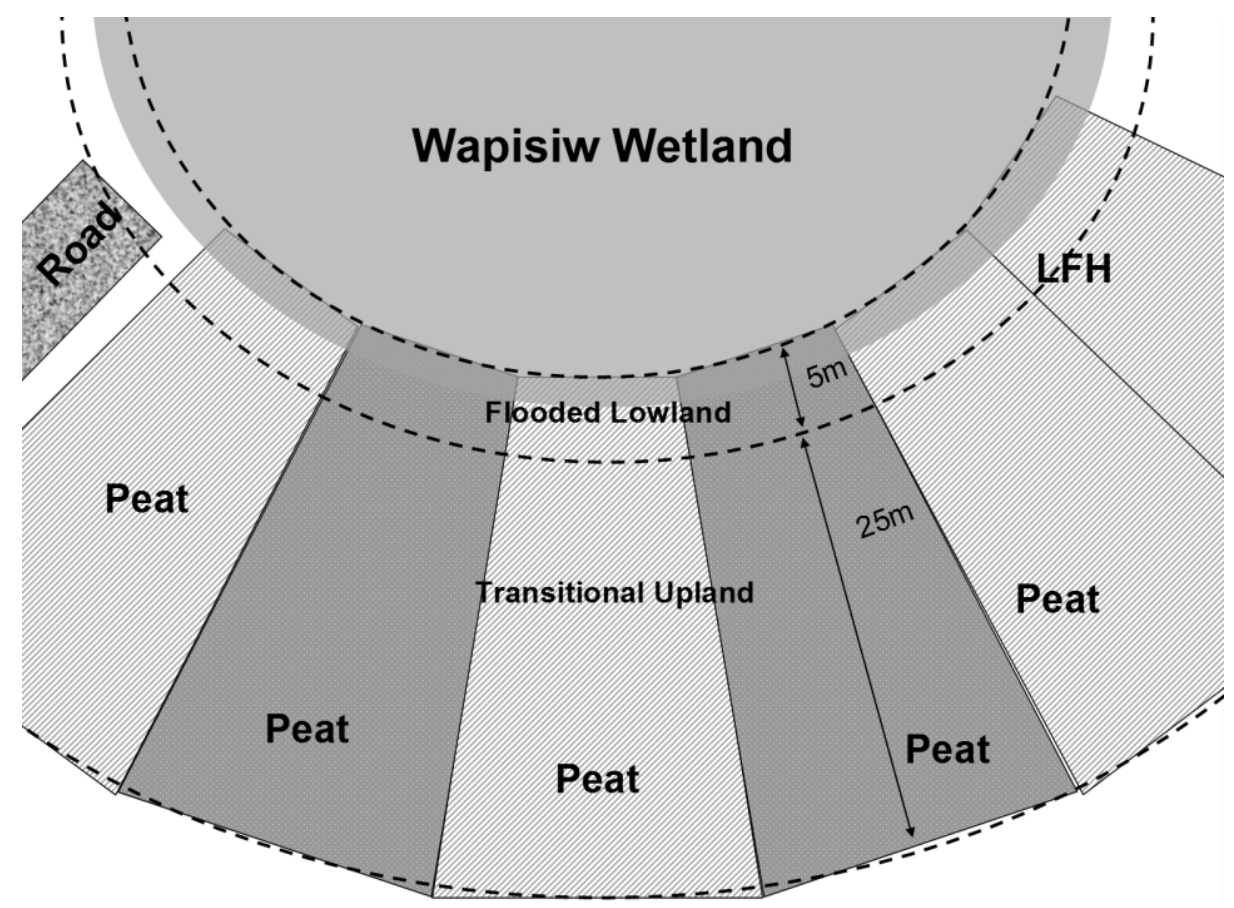

Figure 3 Illustration of the Flooded Lowland (zone 5) and Transitional Upland (zone 3) zones within the riparian experimental plots

The tool suggested that the riparian species with the highest frequency of occurrence within the 'Flooded Lowland - Non-Saline group' were as follows: Aster borealis (marsh aster), Equisetum fluviatile (swamp horsetail), Potentilla anserina (silverweed), Trifolium pratense (red clover), Beckmannia syzigachne (slough grass), Carex aquatilis (water sedge), Carex pseudocyperus (cyperus-like sedge), Salix exigua (sandbar willow), Melilotus alba (white sweet-clover), Typha latifolia (cattail), Carex utriculata (small bottle sedge), Eleocharis palustris (creeping spike rush), Scirpus cyperinus (wool-grass), Scirpus pungens (three-square rush), and Scirpus validus.

The tool suggested that the riparian species with the highest frequency of occurrence within the 'Transitional Upland/Riparian - Non-Saline group' were as follows: Picea mariana (black spruce), Populus balsamifera (balsam poplar), Alnus tenuifolia (thinleaf alder), Betula occidentalis (water birch), Cornus stolonifera (red-osier dogwood), Ledum groenlandicum (common labrador tea), Rubus idaeus (wild red raspberry), Viburnum edule (low-bush cranberry), Epilobium angustifolium (common fireweed), Epilobium glandulosum (purple-leaved willowherb), Equisetum arvense (common horsetail), Meliliotus alba (white sweet-clover), Pyrola asarifolia (common pink wintergreen), Trifolium pratense (red clover), Hylocomnium splendens (stair-step moss), Pleurozium schreberi (schreber's moss), Salix bebbiana (beaked willow), Fragaria virginiana (wild strawberry), Sonchus arvensis (perennial sow-thistle), Calamagrostis canadensis (bluejoint grass), Carex aquatilis (water sedge), Carex disperma (two-seeded sedge) and Aulacomnium palustre (tufted moss).

The following species were intentionally not planted, against the recommendations by the tool, since they were considered weedy or competitive species that were expected to colonise the riparian area without assistance: Meliliotus alba, Trifolium pratense, Typha latifolia, Scirpus validus, Epilobium angustifolium, Fragaria virginiana, and Calamagrostis canadensis. Some desirable species (i.e. Fragaria virginiana) were not planted either since these tend to colonises without assistance. Submergent plants (Potamogeton spp., Myriophyllum sp. and Chara sp.) common to marshes in the region were planted on the edge of the 'Flooded Lowland' zone since submergent areas were not monitored as part of the riparian classification development and hence not recommended by the species selection tool.

Seed was collected for most of the recommended species on Suncor's site between August and November 2009 and propagated in a greenhouse over the 2009/2010 winter season. Species for which seed was not 
collected were transplanted whole from natural or reclaimed wetlands into Wapisiw Wetland on July 22-23, 2010. Species were transplanted in soil plugs (3 plugs per plot) and included: Epilobium glandulosum, Equisetum arvense, Pyrola asarifolia, Aulocomnium palustre, Hylocomnium splendens, Pleurozium schreberi, Aster borealis, Scirpus cyperinus, Drepanocladus aduncus, Scirpus pungens, Potamogeton spp., Myriophyllum and Chara sp.

Due to time constraints, Nuphar variegatum, Eleocharis palustris, Carex disperma, and Carex pseudocyperus were not collected. Although, Carex disperma and Carex pseudocyperus were transplanted as plugs into vegetated floating logs in the wetland and adjacent to the riparian plots and hence may colonise nearby shorelines over time.

Seedlings that were propagated in the greenhouse were planted in the vegetated plots on August 13, 2010 and included the following species: Picea glauca (30; stems/plot), Picea mariana (40), Cornus stolonlifera (30), Alnus crispa (30), Viburnum edule (30), Salix sp. (30), Vaccinium vitis-idaea (30), Ledum groenlandium (30), Populus balsamifera (30), Carex aquatilis (30), Potentilla palustris (5), Carex aethrodes (1) and Oxycoccus microcarpus (10).

A standard reclamation cover crop composed of native bunch grasses (Adanac Slender Wheatgrass (16.9\%), ARC Centennial Canada Wildrye (4.4\%), Rocky Mountain Fescue (13.8\%), Spike Trisetum (7.5\%), Fringed Bromegrass (9.3\%), Junegrass (4.4\%) and Nortran Tufted Hairgrass (6.2\%)) and oats (37.5\%) was sowed in the vegetated plots on July 28,2010 to provide the seedlings with shade and to retain soil moisture in the summer months and provide protection and insulation from snow and cold temperatures during the winter months. The rate of application was $50 \mathrm{~kg} / \mathrm{ha}$. The following parameters were monitored within the riparian revegetation plots in 2010 and 2011: plant survival, \% cover/spread outside plot, water level fluctuations, water/soil chemistry, and plot orientation.

\section{$3 \quad$ Results and discussion}

\subsection{The Riparian classification and reclamation guide}

In total, five zones, 15 groups, nine subgroups and 65 plant assemblages were identified as significant units in the classification for both natural and reclaimed sites (Figure 4). Plant communities in zones were strongly associated with changes in soil moisture, drainage and topography. Plant communities in groups were most closely associated with differences in soil salinity conditions compared to the other study variables. Plant associations in subgroups were associated with differences in soil texture and nutrients. Finally, plant assemblages were distinguished by their dominant physiognomic class (tree, shrub, graminoid, etc.) and plant species cover.

Riparian fact sheets were developed for Zone 3 (Transitional Upland), 4 (Wet Lowland) and 5 (Flooded Lowland) of the riparian classification system. Information on zones 1 and 2 (Dry and Mesic Upland) for terrestrial areas in the Boreal Mixedwood forest of Alberta are available in the Field Guide to Ecosites of Northern Alberta (Beckingham and Archibald, 1996). The riparian fact sheets included a general description, biodiversity elements, key environment conditions and characteristic plant species, including indicator species. 


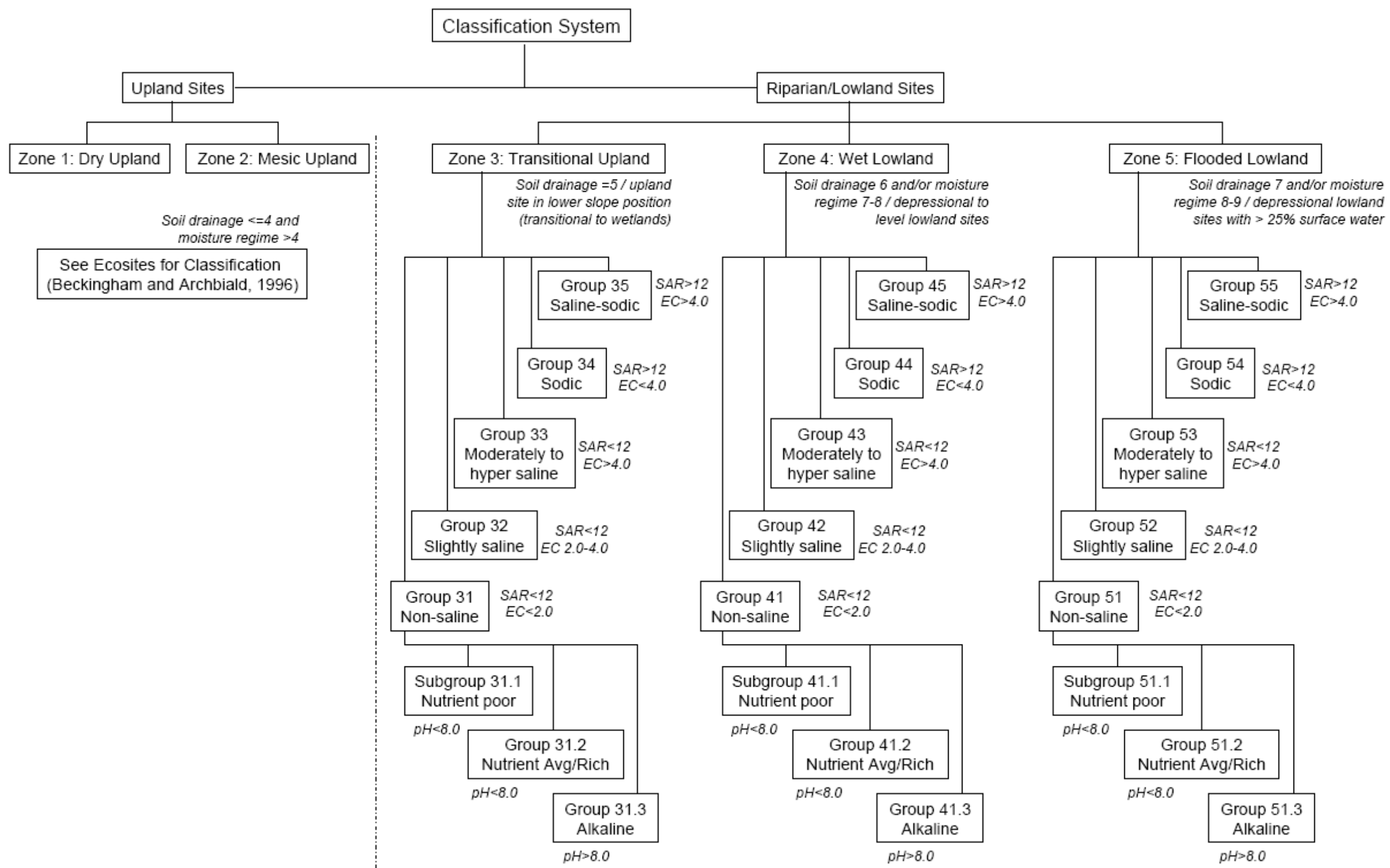

Figure 4 Schematic of the riparian classification system for reclaimed and natural systems (modified from GDC, 2009) 
For example, Zone 3 represents a transitional plant community that is found on the zone of transition between upland and wetland communities (Figure 5). Soils are subhygric to hygric (SMR $=6$ to 7 ) in natural areas, typically found some distance (i.e. 5 to $25 \mathrm{~m}$ ) from the water's edge. Plant communities found here often have a significant tree and/or shrub layer. Species richness for Zone 3 in natural areas was 27.00 \pm 7.25 (mean $\pm S T D ; n=51)$ and $18.80 \pm 8.26(n=78)$ in reclaimed areas. Indicator species in natural areas for this zone included: Picea glauca, Populus tremuloides, Populus balsamifera, Picea mariana, Pinus banksiana, Cornus stolonifera, Rosa acicularis, Amelanchier alnifolia, Viburnum edule, Shepherdia canadensis, Symphoricarpos albus, Rubus Idaeus, Linnaea borealis, Ribes triste, Equisetum arvense, Equisetum pratense, Rubus pubescens, Fragaria virginiana, Achillea millefolium, Cornus Canadensis, Pyrola asarifolia, Hieracium umbellatum, Hedysarum alpinum, Viola renifolia, Trientalis borealis, Poa pratensis, Bromus inermis, Carex aurea, and Hylocomium splendens. Indicator species in reclaimed areas for this zone included: Salix exigua, Salix bebbiana, Taraxacum officinale, Sonchus arvensis, Lotus corniculatus, Aster borealis, Calamogrostis canadensis, Poa palustris, Bromus inermis ssp. pumpellianus, and Carex crawfordii.

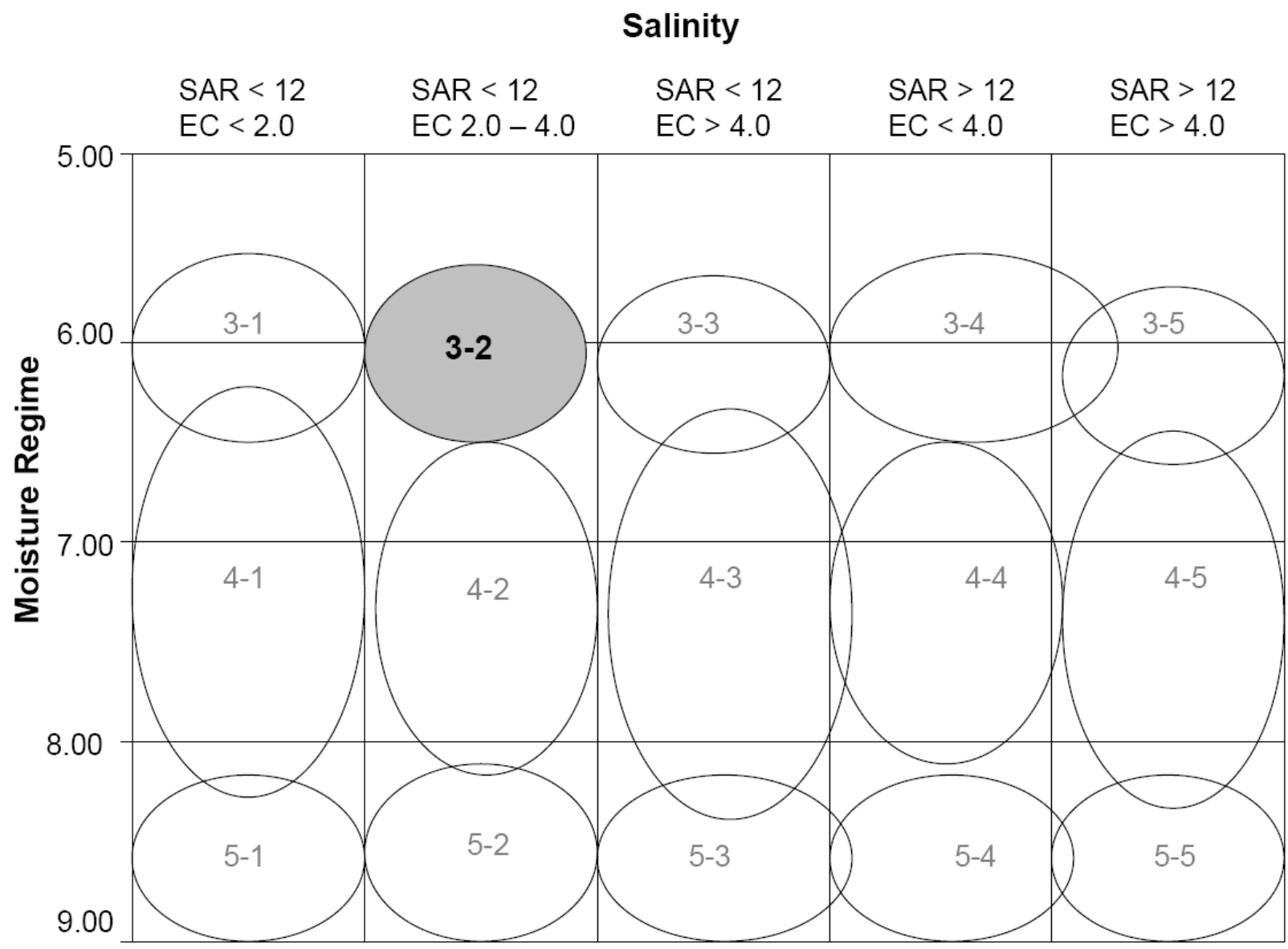

Figure 5 Grid that graphically depicts the location of zones (3-5) and groups (1-5) based on soil moisture regime and salinity (modified from GDC, 2009)

All riparian fact sheets are available in GDC (2009).

\subsection{Riparian revegetation tool}

A 'riparian species-selection tool' was developed to identify the plant species best suited for a particular riparian area based on the moisture regime and salinity position (Figure 6). This tool was developed to guide planners in the revegetation of riparian areas after mining. It identified the plant species with the highest frequency of occurrence and percent cover in natural and reclaimed areas of a particular salinity and SMR. 


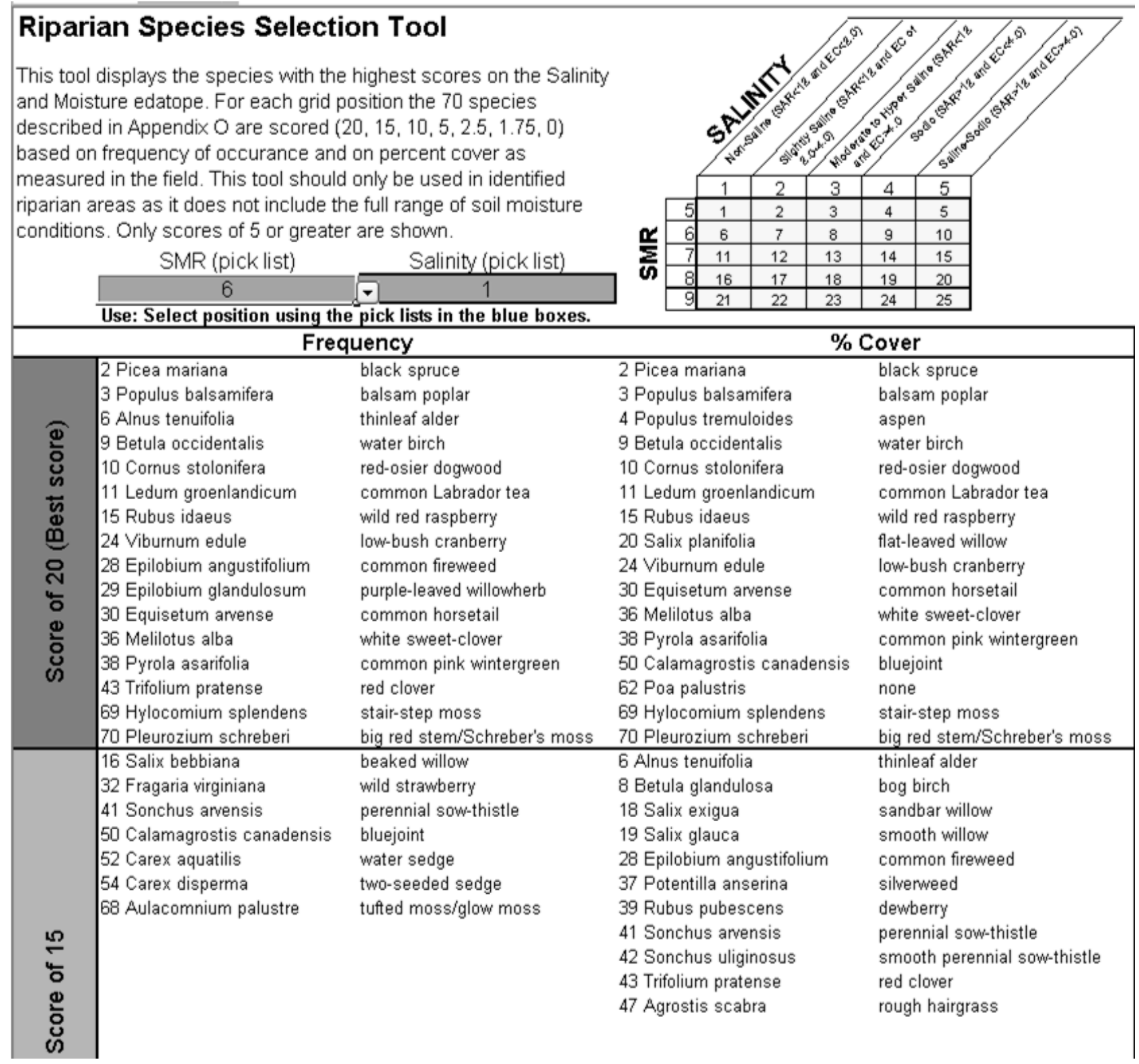

Figure 6 Riparian Species Selection Tool illustrating the species with the highest frequency of occurrence and \% cover in a non-saline and subhygric-hygric (zone 3 ) riparian area (modified from GDC, 2009)

\subsection{Peer review}

The primary strengths of the guide were that it provided comprehensive plant community descriptions linked to their underlying environmental gradients (i.e. riparian fact sheets), revegetation guidance according to site conditions, and a novel and useful species selection tool. The main shortcomings were that the guide lacked design and construction guidance to promote the development of riparian areas in a reclaimed landscape and guidance for assessing the need for management intervention. Other shortcomings were identified in an earlier version of the guide through peer review (i.e. assembly theory was applied inconsistently in the guide) and addressed in the current version of the guide (GDC, 2009).

\subsection{Field trials}

Data collection and analysis is ongoing for the riparian revegetation plots. However, some preliminary conclusions regarding the efficacy of the 'riparian-species selection tool' used to establish the riparian revegetation plots were made. The 'riparian-species selection tool' enabled reclamation planners to easily 
identify optimal plant species for establishment in the riparian areas surrounding Wapisiw Wetland once salinity and soil moisture measurements were quantified and predictions made regarding the long-term site conditions. However, some deficiencies in the tool were noted. First, several weedy and competitive species were suggested for introduction in the reclaimed riparian area, such as Typha latifolia, Scirpus validus, and Calamogrostis Canadensis. These species naturally colonise reclamation areas on their own, so time and costs would be wasted introducing these species. Furthermore, these plants spread quickly and may outcompete other species and/or lead to the development of monocultures. Therefore, some knowledge of riparian systems may be needed in combination with the utilisation of the tool. Second, no submergent or floating plants were recommended by the tool, possibly since monitoring that supported the development of the tool omitted open water zones. Submergent and floating plants should be incorporated into a revegetation plan for reclaimed wetlands so that a similar level of biodiversity and structure found in natural wetlands can be achieved. Third, visual observations suggest mortality was high ( $0 \%$ survival) for the introduced mosses (Aulacomnium palustre and Hylocomium splendens). Planted trees and shrubs near the mosses were only approximately $30 \mathrm{~cm}$ in height and, hence, provided little shade for these understory species that prefer tree-covered areas (Johnson et al., 2005). Perhaps introduction of target species needs to occur at several stages over time as the reclaimed riparian area matures and provides more suitable habitat for species that have specific habitat requirements that are not available immediately after reclamation.

\section{$4 \quad$ Future work}

Future work may focus on addressing gaps identified in the peer review, such as providing more guidance on design and construction and assessment monitoring for reclaimed riparian areas. When gaps are addressed the guide may be recommended by CEMA to the regulators, Alberta Environment and Sustainable Resource Development, as a standard riparian reclamation guide for the Canadian oil sands industry. Data collection and analysis for the field trials will continue in 2012.

The Riparian Guide (GDC, 2009) will soon be available for download at http://cemaonline.ca/.

\section{Conclusions}

The Riparian Guide is a comprehensive guide for riparian plant community establishment along environmental gradients, primarily soil moisture and salinity. Its novel selection tool and facts sheets are useful for reclamation of riparian areas in the Athabasca oil sands region. Ongoing riparian revegetation field trials will guide reclamation practitioners on optimal planting strategies (unassisted colonisation versus planting) according to site conditions and so optimise the efficacy of the riparian species selection tool.

\section{Acknowledgements}

The Riparian Classification and Reclamation Guide (GDC, 2009) was produced by Geographic Dynamics Corp. (GDC) for Shell and Suncor. Funding for guide development was provided by Shell and Suncor. Syncrude provided reclamation monitoring sites in-kind. John David Beckingham (1961-2008) of GDC envisioned the guide and developed a conceptual framework for it. Kevin Kemball and other GDC staff (Margaret Magai, Jennifer Lange, Marcus Ma, Jamie-Lynn Greter, Louise Versteeg, and Vincent Futoransky) were fundamental in completing the guide. Wayne Tedder (Suncor) and Noreen Easterbrook (Shell) provided support, logistics and project direction. Data contributions were provided by Shell, Suncor, Brett Purdy and Syncrude Canada Ltd. Incremental Forest Technologies Ltd. (Kevin Kemball, Milo Mihajlovich, Daniel Chicoine and Sonya Odsen) were commissioned by the CEMA to conduct a peer review, address data gaps and update the guide. Thanks to the Universities of Windsor and Alberta, especially Marie-Claude Roy, for data collection and analysis of the riparian revegetation plots. 


\section{References}

AENV (2007) Alberta Environment. Riparian land conservation and management project: Phase I final report.

Beckingham, J.D. and Archibald, J.H. (1996) Field guide to ecosites of northern Alberta, UBC Press, Vancouver, British Colombia, Canada.

Calvo-Polanco, M., Senorans-Argibay, J., Equiza, A. and Zwiazek, J.J. (2012) Environmental constraints to growth of Rat Root (Acorus americanus), Canadian Oil Sands Network for Research and Development (CONRAD) Environmental Reclamation Research Group (ERRG) Annual Symposium, Edmonton, Alberta, January 30-31, 2012.

CEMA (2010) Cumulative Environmental Management Association. Guidelines for reclamation to forest vegetation in the Athabasca Oil Sands region, 2nd ed (Revegetation Manual), Prepared by the Terrestrial Subgroup of CEMA.

GDC (2009) Geographic Dynamics Corp. Riparian Classification and Reclamation Guide, developed for Shell Canada Energy and Suncor Energy Inc. by GDC, Edmonton, Alberta, Incremental Forest Technologies Ltd 2011, Riparian Classification and Reclamation Guide - Revised, developed for the Cumulative Environmental Management Association.

Golder (2005) Golder Associates Ltd. Consolidated Tailings (CT) Integrated Reclamation Landscape Demonstration Project Technical Report \#5 - Year 2004, Phase 1 Final Report 2000 to 2004, prepared for Suncor Energy Inc Oil Sands.

Hammer, U.T. (1993) Zooplankton distribution and abundance in saline lakes in Alberta and Saskatchewan, Canada, International Journal of Salt Lake Research, Vol. 2 (2), pp. 111-132.

Harris, M.L. (2007) Guideline for wetland establishment on reclaimed oil sands leases (revised second edition), Prepared by Lorax Environmental for CEMA Wetlands and Aquatics Subgroup of the Reclamation Working Group, Fort McMurray, AB.

Jacobs, D.F. and Timmer, V.R. (2005) Fertilizer-induced changes in rhizosphere electrical conductivity: relation to forest tree seedling root system growth and function, New Forests, Vol. 30, pp. 147-166.

Johnson, D., Kershaw, L., MacKinnon, A. and Pojar, J. (2005) Plants of the western boreal forest and aspen parkland, Lone pine publishing and the Canadian Forest Service, p. 309, p. 312.

Korol, J.B. (1996) Riparian forest communities in the Southern Boreal Region of central Saskatchewan, Prince Albert Model Forest Association Inc., Prince Albert, Saskatchewan.

McCune, B. and Mefford, M.J. (1999) Multivariate analysis of ecological data, Version 4.14 PC-ORD for Windsors, MJM Software, Gleneden Beach, Oregon, USA.

OSWWG (2000) Oil Sands Wetlands Working Group. Guidelines for wetland establishment on reclaimed oil sands leases, N. Chymko (ed), Rep. ESD/LM/00-1, Alberta Environment, Environmental Services Publication No. T/517, 2000.

Pouliot, R., Rochefort, L. and Graf, M.D. (2012) Impacts of oil sands process water on fen plants: Implications for plant selection in required reclamation projects, Environmental Pollution, Vol. 167, pp. 132-137.

Purdy, B.G., Macdonald, S.E. and Lieffers, V.J. (2005) Naturally occurring saline boreal communities as models for reclamation of saline oil-sands tailings, Restoration Ecology, Vol. 13, pp. 666-677.

Renault, S., Paton, E., Nilsson, G., Zwiazek, J.J. and MacKinnon, M.D. (1998) Responses of boreal plants to high salinity oil sands tailings water, Journal of Environmental Quality, Vol. 28 (6), pp. 1957-1962.

Rezanezhad, F., Andersen, R., Pouliot, R., Price, J.S., Rochefort, L. and Graf, M.D. (2012) How fen vegetation structure affects the transport of oil sands process-affected waters.

Timmer, V.R. and Teng, Y. (2004) Pretransplant fertilization of containerized Picea mariana seedlings: calibration and bioassay growth response, Canadian Journal of Forest Research, Vol. 34, pp. 2089-2098.

Trites, M. and Bayley, S.E. (2009) Vegetation communities in continental boreal wetlands along a salinity gradient: Implications for oil sands mining reclamation, Aquatic Biology, Vol. 91, pp. 27-39.

Vitt, D.H., Halsey, L.A., Thormann, M.N. and Martin, T. (1996) Peatland Inventory of Alberta, prepared for the Alberta Peat Task Force, National Centre of Excellence in Sustainable Forest Management, University of Alberta, Edmonton.

Warrence, N.J., Bauder, J.W. and Pearson, K.E. (2002) Basics of salinity and sodicity effects on soil physical properties, Department of Land Resources and Environmental Sciences, Montana State University. 